\title{
Does capitalism have a future? A review essay of Peter Boettke's The Struggle for a Better World and Daniel Bromley's Possessive Individualism: A Crisis of Capitalism
}

\author{
Ilia Murtazashvili ${ }^{1}$ (1)
}

Accepted: 15 September 2021

(c) The Author(s), under exclusive licence to Springer Science+Business Media, LLC, part of Springer Nature 2021

\begin{abstract}
In this review essay, I compare and contrast Peter Boettke's The Struggle for a Better World (Mercatus Center, 2021) and Daniel Bromley's Possessive Individualism: A Crisis of Capitalism (Oxford University Press, 2019). Each of these books considers the future of capitalism. Boettke's Struggle sees capitalism as the only morally and economically justifiable system but that continual effort is necessary to ensure the capitalist enterprise succeeds. Bromley's Crisis sees capitalism as a spent force that no longer does what it was meant to do-namely, improve the economic well-being of households. There are surprisingly many points of agreement in these books, most notably a concern for the downtrodden in society and an appreciation for the legitimation crisis confronting capitalism. There are also important differences that will give anyone interested in the future of capitalism much to ponder. Boettke sees unconstrained government as the primary threat to legitimacy; Bromley identifies the possessive individualism that lies at the heart of our current capitalist system as the source of the crisis. Both books make a significant contribution to our understanding of the institutions governing capitalist economies and powerful arguments as we contemplate the future of capitalism.
\end{abstract}

Keywords Capitalism $\cdot$ Institutions $\cdot$ Individualism $\cdot$ Markets

JEL codes $\mathrm{B} 52 \cdot \mathrm{H} 1 \cdot \mathrm{N} 3 \cdot \mathrm{P} 1$

Ilia Murtazashvili

ilia.murtazashvili@pitt.edu

1 Graduate School of Public and International Affairs, University of Pittsburgh, Pittsburgh, PA 15260, USA 


\section{Introduction}

Does capitalism have a future? In this review essay, I compare and contrast two books that offer sweeping, insightful accounts of the past, present, and future of capitalism. Peter Boettke's The Struggle for a Better World (2021) (hereafter Struggle) is an eloquent defense of liberalism-a "doctrine of economic and political life grounded in the recognition that we are one another's dignified equals, and that justice demands equal treatment of equals" (p. 7). Liberalism is about power for the people, not the privileged elites. Boettke's collection of essays offers a superb defense of capitalism grounded in an appreciation for the way that spontaneous order makes the best use of the human imagination and a deep concern for the damage done when government becomes unshackled Leviathan.

Daniel Bromley's Possessive Individualism: A Crisis of Capitalism (2019) (hereafter Crisis) sees capitalism as a spent force because its concern with improving the well-being of households has been replaced by its singular focus on profiting by what Bromley calls "wrangler capitalists" - those capitalists who specialize in buying, selling, and reorganizing businesses (pp. 55-56). According to Bromley, the problem is possessive individualism: an overwhelming concern is to "stay focused on controlling costs," much like what a comptroller does (p. 23). Economics used to be concerned with how households provide for themselves but has become preoccupied with the atomistic individual. Did, as Boettke suggests, and as Deirdre McCloskey and Art Carden (2020) have persuasively argued, liberalism make us better and richer humans? Not so, for Bromley. We have more stuff, but what about the quality of our working lives? For many workers, the current situation is nothing to gloat about.

Each author speaks from a position of credibility as a scholar and institution builder. Boettke has done as much as anyone to advance contemporary Austrian economics. Bromley is known for work in the tradition of the so-called old institutionalists, such as John Commons. There are important differences between the traditions. For one, Austrians and institutionalists differ in their beliefs about general economic truths: Austrians think there are such truths but question whether mathematical formalism is the way to find them, while institutionalists, especially the old institutionalists, find such truths chimeral (Boettke et al., 2003).

Despite differences in their perspectives, these books have much in common. The shared framework should not come as much of a surprise. Though institutionalism is sometimes contrasted with institutionalism in economics, Austrians, as Boettke (1989a) explains, are and always have been institutionalist. Austrian institutionalists such as Hayek and Mises are completely in agreement with the old institutionalists (and the new version) that the structure and scope of economics ought to be concerned first and foremost with "the consequences of alternative institutional arrangements" (Boettke, 1989b, p. 78). Simply put, Austrian economics is institutional economics (Palagashvili et al., 2017).

Besides a shared concern with institutions, each of these books recognizes a legitimacy crisis. Boettke's Struggle begins by noting that trust in public 
institutions of governance, private institutions of finance and commerce, and social institutions of community are confronting a severe stress test. For example, George Floyd's murder cannot be tolerated in a liberal society. Rust Belt cities such as Detroit and Pittsburgh continue to grapple with economic malaise, despair, and addiction. True radical liberals, as Boettke explains, have inherited a problematic past and face a troubling present. There is no shortage of interesting work pointing out how we are so much better off now than in earlier centuries. But pointing out how economic freedom is associated with wealth does not really explain why there is so much anger, and the fact is that much of the world remains extremely poor. Boettke knows not all is well in society, though liberalism is not the problem.

Bromley's Crisis is motivated in part by the recent electoral victory of populist leaders, including Donald Trump. Trump is a grifter, but this surprising victory was not a cause of the crisis. Trump, in Bromley's words, is "merely a noxious messenger" (p. 232). Bromley contends that people are angry because managerial capitalism, with its emphasis on cutting costs, has failed them.

John Meadowcroft (2019) explains that James M. Buchanan was especially concerned with the status of the status quo. So too are Boettke and Bromley's books. But their understandings of the causes differs. Boettke argues that public misconduct, not private misconduct, ruins nations. Unshackled Leviathan is the problem. For Bromley, the problem is capitalism.

My goal in this review essay is to consider where these books differ in their understanding of capitalism, their diagnosis of the problem giving rise to the legitimation crisis, and their suggestions about what ought to be done. It is not to choose one argument over another. Each of these books masterfully weaves together insights gained through the authors' decades of careful inquiry on the nature of capitalism. Each shows a masterful understanding of institutions. I hope that anyone especially optimistic about capitalism will take Bromley's critique seriously and that anyone especially optimistic about government's ability to solve the problem will consider carefully Boettke's impassioned arguments.

The rest of this essay is structured as follows. First, I suggest that an important difference is that Struggle focuses on capitalism as exchange of goods and services, while Crisis places much more emphasis on the transition from merchant capitalism to industrial, then financial, and then managerial capitalism. By the time we get to managerial capitalism, goods and services are still exchanged, but labor has far less bargaining power under the current system of capitalism than under previous ones. Next, I consider differences in how these books conceptualize the problem: Boettke's issue is with government, while Bromley's is with possessive individualism. Finally, I contrast the two authors' advice about the future.

\section{Capitalism or capitalisms?}

Boettke's Struggle places Adam Smith at the forefront. One might think this is an obvious starting point since we are concerned with economies. But anyone familiar with the typical PhD program's course sequence in microeconomics will know that Smith is treated as a footnote in a course devoted mainly to proving one's mathematical chops. 
But ignoring Smith has significant costs, especially if we are concerned with vulnerable people. In Boettke's hands, Smith becomes a figure much like Johnny Cash: someone profoundly concerned with the voiceless and the downtrodden. Liberalism, as Boettke explains, means extending a hand to strangers in order to lift the dispossessed and the desperate out of poverty. ${ }^{1}$ Smith's Wealth of Nations argued that individuals should be free from domination and that those who are more powerful should not determine the material conditions of those who have less power because no society can flourish if the greater part of its members are poor and miserable. This is the central theme in the liberal tradition. F.A. Hayek understood the liberal project as the abolition of privileges of the few that kept down the many. It is a point made explicitly in the 1956 edition of The Road to Serfdom "The essence of the liberal position is the denial of all privilege, if privilege is understood in its proper and original meaning of the state granting and protecting rights to some which are not available on equal terms to others" (1956 [1994], p. xxxvi). In addition, in The Constitution of Liberty, Hayek states that the "true contrast to a reign of status is the reign of general and equal laws, of the rules which are the same for all, or, we might say, of the rule of leges in the original meaning of the Latin word for laws - leges that is, as opposed to the privi-leges" (emphasis original, Hayek, 1960, p. 154). Buchanan believed that the struggle for political liberalism is an effort to free individuals from the ruling elite. Boettke favorably references McCloskey's Why Liberalism Works (2019) in noting that true liberalism means no racism, no imperialism, no unnecessary taxes, and no slaves at all. ${ }^{2}$

Boettke's essays (Crisis is a collection of essays bookended by a wonderful introduction and conclusion) are exceptionally useful as a corrective to any argument that classical liberalism supports oppressive institutions such as slavery and segregation. Others have debunked such arguments (see, for example, Fleury and Marciano 2018). Struggle is not a direct response to those criticisms. Rather, it shows that Smith was an ardent defender of consent as a general organizing principle and an enemy of privilege as a means of organizing economic activities.

But could Smith have foreseen the evolution of capitalism? And should we place blame on government when capitalism and democracy seem so intrinsically bound up that it seems impossible to even separate them? ${ }^{3}$ Bromley's Crisis recognizes that the capitalism that Smith understood so well has changed a great deal since his time. And we know that the core of Bromley's book is to analyze the transition from merchant capitalism to industrial capitalism to financial capitalism and, finally, to the managerial capitalism of today. These gradual shifts are characterized by "the primacy of a central personified medium-the entrepreneur of merchant capitalism, the engineer of industrial capitalism, the banker of financial

\footnotetext{
1 See also William Easterly's (2020) brilliant essay on Adam Smith's anticolonialism.

${ }^{2}$ Boettke might also have added W.H. Hutt to the list of liberals against racism, as Hutt's impassioned critique of apartheid was based on an appreciation for consumer sovereignty (Magness et al., forthcoming).

3 Randall Holcombe's (2018) concept of political capitalism also gets at Bromley's concern about the close relationship between economic and political elites in capitalist democracies.
} 
capitalism, and the wrangler of today's managerial capitalism" (emphasis original, p. 55). ${ }^{4}$

Bromley's description of capitalism is significant and useful, especially when we consider that Smith introduced new ideas about how we think about capital and capitalism. ${ }^{5}$ Before Smith wrote about it, capital was a sum of money that was to be invested or had been invested. But then it became the things themselves - the goods traded. Conceptualizing of capital as physical things and capitalism as exchange was a historical sleight of hand, one with important consequences: it makes us lose track of the changes in capitalism since we become concerned with physical things rather than legal relationships and the rules governing capitalism.

Smith's novel approach to capital and capitalism meant that the conversation about capitalism was often less institutionally rich than it could have been. This does not mean Smith had no role for institutions. Gary Anderson and Robert Tollison (1982) showed that Smith was critical of the English East Indian Company. Smith believed the problem was government failure rather than a market failure. And Nathan Rosenberg recognized Smith's preoccupation with establishing the conditions under which market mechanisms operate most effectively and that tree operation of "certain impulses, motivations, and behavior patterns were calculated to thwart, rather than to reinforce, the beneficent operation of market forces" (1960, p. 569). Institutions, including government ones, are necessary because cooperation is not inevitable. Rather, Smith's institutionalism, like Boettke's, focuses on the political side of the institutions governing capitalism as the problem. ${ }^{6}$ Thus, when Smith speaks of capitalism requiring an appropriate constitutional framework, it is mostly about ensuring that the government limits its activities - a view quite similar to Boettke's Struggle. Bromley, in contrast, is much more interested in the evolutionary stages of capitalism, and the consequences of these shifts.

What changes ought we to be concerned with? The rigid hierarchies of precapitalist relations came under pressure as labor's bargaining power improved as a result of plague and warfare in the fourteenth century. By the end of the fourteenth century, most agricultural laborers had become quasi-independent agricultural entrepreneurs who were no longer willing to underwrite wars. Copyhold emerged as an institution - and with it, rental contracts to use land replaced in-kind payment for privileges to use land. Now lords held the king's land and independent families held the lord's land. Copyhold put us on the road to fee simple, the most complete property right. ${ }^{7}$ This institutional development enabled the rise of merchant capitalism and

\footnotetext{
${ }^{4}$ One could, as Aligica and Tarko (2015) suggest, simply do away with the notion of capitalism and recognize that we are dealing with capitalisms: crony capitalism, state capitalism, and so on. Bromley's classification of capitalisms is a useful complement to the ones familiar to those in the public choice literature.

${ }^{5}$ Two excellent books on the meaning of capitalism and the significance of legal rules are Geoffrey Hodgson's Conceptualizing Capitalism (2015) and Katharina Pistor's The Code of Capital (2019).

${ }^{6}$ If there's a limitation with Smith's view, it may be that he did not anticipate how well self-governance works when people have these conflicts of interests. Peter Leeson's Anarchy Unbound (2014) shows just how well it works, and why.

${ }^{7}$ Though much attention is paid to fee simple, the most significant conclusion of the property rights approach regardless of school of thought-Austrian, public choice, or Ostromian-is that the most appropriate property regime is one that evolves in response to local conditions (Harris et al., 2020).
} 
the entrepreneur, but much would be lost as capitalism evolved. Workers lost control of their means of production (labor) with the rise of industrial capitalism and the factory system and the accompanying separation between owners of capital-commercial land, sophisticated machines, large factories - and owners of labor power. Labor then became a commodity to be bought and sold just like any other factor of production. McCloskey's Bourgeois Dignity (2010) concerns how we talk about entrepreneurs. Bromley's concern is with the rise of a body of compliant laborers whose lives are very different from those of entrepreneurs.

The factory system was not the only development. Financial capitalism-which came because industry at a massive scale required financing on a grand scaleintroduced rapid movement of liquidity around the world. But that was not the end. In managerial capitalism, "the wrangler rules. The entrepreneur of merchant capitalism surrendered his autonomy to the engineer of industrial capitalism. The engineer was soon pushed aside by the money managers and bankers of financial capitalism. Now, it seems reasonable to suggest that the financial wizards are answerable to the wrangler. Someone very meticulous is now minding the store" (Bromley, p. 82).

Bromley then shifts to an argument that scholars interested in collective action will appreciate. He describes firms as hedgehogs and households as foxes. Hedgehogs know one thing and foxes know many. Households, under managerial capitalism, have to know many things, and some even have to hold several jobs. The firm, however, is an artificial construct with a singular goal: to lower costs. It is for this reason that the hedgehogs dominate the foxes; the foxes have no chance. Walmart and Amazon are too big to resist. The foxes face a much larger collective action problem, one that is exacerbated by the massive scale of capitalism.

Boettke's essays do not focus as much as Crisis on the historical evolution of capitalism; rather, they focus on the importance of freedom of choice. Struggle defends significant figures such as Ludwig von Mises, Hayek, and Milton Friedman. Bromley counters the arguments of the great defenders of capitalism. Freedom of choice-not being forced to work a specific job-is a narrow conception of freedom. Freedom to choose means little if the choice set, which is shaped by institutions, is not of our choosing. Bromley puts it this way: living is good (we have more stuff to consume), but what about work life? Capitalism is thriving in some parts of urban areas, but anger with the current situation is especially pronounced in rural areas in the United States, Britain, and Western Europe. And outside of those countries, many countries have experienced little improvement in material conditions in the past several centuries. Some workers may enjoy the life of the fox, moving from job to job in the gig economy, but for many, there is despair: "The unavoidable consequence of possessive individualism is that capitalism no longer comprises a source of hope. It has evolved into a system-an 'ism' —-without a compelling moral basis for its continuation" (Bromley, p. 123).

These books thus differ in what they mean by capitalism: trade in goods and services (in Struggle) or trade in labor (in Crisis). However, each aspect of capitalism is significant, and so they are in a sense complementary contributions. Trade in goods and services has its benefits, though the increase in goods and services available to us comes with greater vulnerability for households excepting their greater 
consumption choices. Together, the books offer profound insight into the productive power of capital and its costs.

Another reason to praise Boettke's and Bromley's books is that they move beyond Thomas Piketty's (2014) concern with the empirical relationship between inequality and capitalism in at least three ways. First, they remind us that any attempt to relate capitalism to inequality leaves out important changes in the nature of capitalism over the past several hundred years. This is significant because unless we understand which capitalism we are talking about, we may misdiagnose the problem. Second, Boettke and Bromley each recognize that anger and illegitimacy are based not on inequality but on vulnerability. They disagree about their source of the problems: for Boettke, vulnerability is a result of government or regulation; for Bromley, capitalism - specifically, what he calls wrangler capitalism (and before it, industrial capitalism - is the reason households struggle to find meaningful employment). Third, it is abundantly clear that the wealth tax suggested by Piketty and increasingly supported by politicians is a magic bullet. Rather, our focus, if we agree with Boettke, is that we ought to be concerned with political institutions (why should we expect that the revenues will be spent addressing the real problems?). And if we agree with Bromley, we ought to direct our concern to economic institutions, not simply fiscal policies (why should we expect a wealth tax will solve the problem of vulnerability, if managerial capitalism remains unimpeded?).

One term that does not come up much in either book is neoliberalism, and for good reason: the term is often used as a pejorative to criticize a certain group of economists. ${ }^{8}$ Critics of "neoliberalism" would do well to consider carefully specifying what kind of capitalism they are talking about and whether they have accurately diagnosed the problem they see, and whether it works. ${ }^{9}$ Bromley's work suggests their concern is not so much with the recommendations of scholars such as Friedman as with the specific institutional features of capitalism as we currently experience it, while Boettke suggests that the problems they see may be government failures rather than problems with supposedly laissez-faire economic policies.

\section{Is unshackled Leviathan or capitalism the problem?}

Each offers a diagnosis of the problem. In Struggle, the diagnosis is public predation. In Crisis, it is possessive individualism and the collective action problem confronting workers in their dealings with firms.

In chapter 2 of Struggle, "Economics and Public Administration," Boettke contends that an institutional framework is necessary to realize gains from exchange because of the paradox of government: addressing private predation opens the

\footnotetext{
${ }^{8}$ Nick Cowen's (2021) perspective offers a compelling and productive framework that eschews the desire to see neoliberalism as a bogeyman standing in for policies one wishes to criticize.

9 For an excellent discussion of the history of the term neoliberalism, see Leeson and Harris (Forthcoming). They also explain why there is no good reason to see Hayek as a neoliberal who only argued for market fundamentalism. Some of Hayek's writing were very much opposed to state efforts to implement markets, as Hayek of course understood the knowledge problem of doing so.
} 
possibility of public predation. The fundamental cause of development-as viewed by scholars from Mises to McCloskey-is ideas about what to produce and how to produce it, as well as idea about what kinds of rules make savings and capital accumulation safe. That is, idea about how to govern ourselves.

Chapter 5 of Struggle (aptly titled "Is State Intervention in the Economy Inevitable?") argues that government intervention in the economy is not inevitable but probable without restraints on government, given that the demand for state intervention is constant. Chapter 6 is a clearly written essay that eloquently argues that government overspends because it has too much power. Nor is the problem with the people. One of the things that comes out in this book is Boettke's deep appreciation for the role of institutions as an explanation of our current situation. As Boettke explains, "Blaming public unions for asking for improved benefits from their members or blaming elected officials for responding to those demands in order to win votes is like criticizing a wasp for stinging you when you step on its nest. The problem isn't the people; it is the institutional regime that produces the pattern of behavior" (Boettke, p. 126). Like Bromley, Boettke is concerned above all with institutions and their consequences.

Boettke, as we know from his Public Administration in the Classical Liberal Tradition (Aligica et al., 2019), written with Paul Dragos Aligica and Vlad Tarko, is deeply appreciative of Vincent and Elinor Ostroms' vision of public administration. The essays of Struggle show the evolution of many of the ideas in the earlier book. In the emergent view of public administration, the idea of a unitary state populated by omniscient and benevolent expert bureaucrats is rejected in favor of a view of government populated by ordinary individuals who have limited knowledge and respond to incentives. This is the Ostromian vision. The implication is clear: we ought to adjust our expectations of what to expect from bureaucrats. Public entrepreneurs are the ones with the vision required to make changes, though making changes requires that these entrepreneurs and those who they interact with have some autonomy. The problem is not government. Our central problem is that government has gotten out of hand and that we have collectively moved away from the Ostromian vision of self-governance as the unifying theme of public administration.

Most of the examples in Boettke's book are examples of unshackled Leviathan doing bad things. This is most obvious in his reflections on the evils of what Geoffrey Hodgson (2019) calls "big" socialism: central planning. But so too are there many significant examples of government predation, including in policing-arguably one of the most significant examples of the predatory state in society. ${ }^{10}$

Turning to Crisis, we direct our gaze to the problems arising from capitalism. Central to Bromley's diagnosis of the problem is the parable of the fox and the hedgehog. As noted above, managerial capitalists are the hedgehogs; households and workers are the foxes. The foxes of the world have to deal with increasing atomization: "In a fully atomized world, the flowering of meritocratic processes then tends to threaten political coherence and a shared sense of purpose within a

\footnotetext{
${ }_{10}$ Brandon Davis (2021) explicitly places the American carceral state in the framework of the predatory state.
} 
community. Meritocracies reward merit, but they also begin to generate institutional arrangements-public policies - that tend to reinforce such self-interested inclinations" (Bromley, p. 16).

Bromley points to economics as the dubious enabler of the hedgehogs. Economics shifted its concern from organization to the atomized individual. It was originally concerned with how individuals and societies organize to provide for themselves. The two key organizations are the household (which is natural) and the firm (which is artificial). But then formalism took hold, and the maximizing individual became sovereign. Possessive individualism is the view that individual rationality and the sanctity of the consumer are the most significant building blocks of the economy. This view overlooks that there had to be organizations in order for there to be something to trade. As far as I can tell, Bromley and Boettke are fully in agreement on the problems that arise from the Max U or "man as machine" approach in much of economics. $^{11}$

Crisis offers up possessive individualism as the cause of the current dissatisfaction with capitalism. Bromley engages a topic of concern to many in the Austrian tradition: do markets make us more virtuous than we would otherwise be ${ }^{12}$ Bromley summarizes the case that markets make us moral as follows. Market economies come to be composed of individuals who are socialized to master the virtuous character traits of market societies. These acquired traits are inevitable consequences of the need to orient one's actions toward mutually advantageous social interactions, which are the reason why societies adopted markets in the first place.

Bromley's response to the markets-as-moral-spaces argument is that its proponents are concerned only with buyers and sellers seeking to exchange commodities or services in a normal market. However, the desire to engage in market transactions is not itself a virtue, as many exchanges are repugnant and many choices are not good even for the individuals doing the choosing. Most significantly, most of these market transactions reapportion wealth rather than create new wealth.

Any focus on buying and selling is thus incomplete. Labor has been commodified, and many workers cling to the belief that they need choice. But workers now have fewer choices and much less bargaining power. The hedgehog dominates under managerial capitalism, and many foxes do not even know it, and when they do, they cannot really do much about it. This is not a problem that arises from government. Rather, it is a problem of capitalism; more fundamentally, the problem is that the ideology of possessive individualism has been wielded to justify the institutions that give rise to the anger that has contributed to deplorable phenomena such as Trumpism.

These books are also an invitation to additional empirical research. Bromley offers sweeping critiques of managerial capitalism, with a masterful institutional analysis of our current situation. But many of the contentions are empirical ones.

\footnotetext{
11 Indeed, Boettke et al. (2003) contend that only the Austrians and old institutionalists truly put people at the forefront of analysis.

12 Anyone looking for a response to Bromley's criticism would do well to consider Ginny Choi and Virgil Storr's Do Markets Corrupt Our Morals? (2019).
} 
Does the market erode social capital? Mark Pennington and John Meadowcroft (2008) find that spontaneous order produces bridging and bonding social capital. Art Carden recently notes that Walmart is not as bad as it seems, contrary to corporate dystopia narratives in the tradition of John Kenneth Galbraith's New Industrial State (1967). While Walmart is one of the largest firms in the world by profits, its profits are only about one-tenth of one percent of US GDP (Carden, 2021). Carden's empirical studies provide further evidence that Walmart is actually good - there is less hunger (Courtemanche \& Carden, 2011), more art and leisure (Carden \& Courtemanche, 2009), and no decline in social capital, such as club membership, in communities with a Walmart (Carden et al., 2009). One might see this as empirical evidence in support of Boettke, though for reasons noted, Bromley is certainly on to something, as the anger with the current work situation is still palpable, despite low prices.

It is straightforward to see how Bromley and Boettke differ. It is certainly true, as Boettke claims, that goods being reshuffled and reallocated in response to changes in prices can be a good thing-even a great thing, as we know from Amazon Prime getting many of us through the COVID-19 pandemic or from how the supply lines for toilet paper and paper towels came through despite the hoarding behavior of some customers. But what if we replace goods and services in the above account with workers reshuffled and reallocated in response to changes in prices? After all, the definitive change in capitalism as we moved from merchant capitalism to industrial capitalism is that the worker became a fictitious commodity. Foxes are not simply buying goods and services; they are goods and services. The point here is not to choose a side, but to note that the Industrial Revolution ensured that the question of what is being purchased would become not only about the stuff we want, but about labor.

Another difference worth noting is about embracing people with open arms. Libertarians will love Boettke's characterization of welcoming strangers with an open hand. ${ }^{13}$ Bromley's perspective is a bit more nuanced. The reason why people want to come to countries such as the United States is not that they do not have market freedom. Many African countries have an abundance of market freedom, but that is not enough to provide political order. Nor is it clear that the open hand comes without costs. George Borjas (2016) has made this point in reflecting on immigration. Nor is xenophobia or racism the obvious reason why people support Trump, as some workers have rational reasons to worry about their situation with inflows of people (Murtazashvili et al., 2021). But this should be clear enough from any economics lesson on immigration, since the argument is about net benefits from immigration, not that every single person is better off with new entrants into the labor force. And we cannot necessarily rely on government to address the challenge that comes with new migrants to a region, as those who are left out do not always feel they have much voice in politics. Possessive individualism is part of the reason people want to leave one place; and in their destination, its pernicious effects on politics mean that those

\footnotetext{
13 Ben Powell and Alex Nowrasteh (2020) make an important case that the benefits of immigration exceed its costs.
} 
people may be subject to the same forces of insecurity and instability brought on by wrangler capitalists. Bromley's point is that today's immigrants might be the disaffected Rust Belt workers of tomorrow, and we ought to spend more time thinking about why the disaffected Rust Belt workers might be concerned about immigration beyond merely asserting that they are economically irrational or xenophobic racists.

\section{What is to be done?}

Struggle leaves no uncertainty about what is not to be done: "There is no justice to be achieved from socialism, only equality in misery and despair as daily life devolves into one of economic deprivation and political terror" (Boettke, p. 7). The case is made more fully in Boettke's collection of essays titled Calculation and Coordination (2001). Socialism ought to be eliminated from the menu of potentially desirable organizational forms of economic, political, and social life. Chapter 13 ("Rebuilding the Liberal Project") is more constructive in suggesting that the liberal project cannot be saved by repackaging a fixed doctrine of eternal truths. True liberalism faces a threat from conservative movements on the right and socialism on the left. In the US and the UK, the populist threat comes from both the Left and Right. Liberalism above all is about toleration. The answer to populism is toleration. Cosmopolitanism is the answer to populism. Boettke's argument is a case for freedom to choose. ${ }^{14}$ One of the reasons openness is justified is, per Julian Simon (1981), that the ultimate resource is human imagination.

Boettke's concluding chapter provides one of the most eloquent defenses of the liberal society as an open society. Libertarian champions of economic freedom would do well to consider Boettke's nuanced perspective on the current situation. At best, we have pockets of liberal commerce that raise living standards tremendously. At worst, we have power and privilege. There is a growing concern about global inequality. In the end, the struggle of ideas is about correcting two misconceptions: (1) the rich get rich at the expense of the poor, and (2) the poor do not get rich faster than the rich get richer. Critics point to neoliberalism as the problem. Boettke explains why we ought not to do that.

For Bromley, inequality is the intended result of possessive individualism, which compels individuals to pursue a livelihood strategy, including the types of jobs we choose and what we collectively expect of our workers, based on the celebration of rights and the illusory idea of being free to choose. Despite many individuals believing that individualism is the only and right way to organize society, they seem not to realize that they are at the mercy of capitalist firms equally committed to possessive individualism, and that when push comes to shove, the capitalists mostly win. Consumers, as Bromley notes, are often all too eager to denounce China for predatory trade policies while filling up their

\footnotetext{
14 Ilya Somin's (2020) discussion of foot voting fits nicely with the defense of freedom to choose: through foot voting, people can choose better institutions, including political ones, and contribute to greater political freedom. Foot voting is just limited to voting, but where one lives, among other things.
} 
minivans with abundant clothing, toys, and plastic products from China. Lower prices are a good thing. But Bromley argues that that is not a good reason, but rather an excuse. The more honest reason why consumers continue the endless quest for bargains is the "enduring culturally prized urge toward persistent lowcost acquisitiveness" (p. 237).

Bromley is not engaging in Marxist false consciousness theorizing. Rather, it is an empirical statement that many of the policies individuals support contribute to the vulnerability of workers and that the fact that they have more choice does not eliminate the more general precarity of their work situation. Low-cost acquisitiveness has costs.

One might of course respond that individualism is not necessarily bad, especially when we think of individualism as inquisitiveness and hard work. Certainly the empirical literature finds that individualism is associated with greater wealth (see, for example, Williamson and Mathers 2011). Bromley's criticism is different. Freedom has come to mean aggressively pursuing self-interest and desiring to make sure others do not have what we enjoy. Possessive individualism is not the social capital that Boettke and colleagues have so clearly shown to be significant in responding to crises (Boettke et al., 2007). Overcoming possessive individualism - crass individualism - requires us to recognize that we can reconstitute a market economy in the interest of greater equality and other-regarding behavior. The capitalist firm must be transformed into a public trust. However, this will not be sufficient. Improved livelihoods will also require that the possessive individual be reimagined.

Bromley notes that the word "community" is now used to separate us into silos, a practice facilitated by identity politics. Rather than separating ourselves, it is crucial to recognize that personhood requires a community that acknowledges one's personhood. It requires engagement. But managerial capitalism denies the relevance of community. Mindless and numb workers are the new automatons. Ultimately we need exchange on equal terms since under managerial capitalism the fox always loses.

These books also discuss the future of economics as a science. One of Boettke's contributions is demonstrating the ongoing significance of the classical liberal tradition. Economics has lost its way in its search for clever research designs and its focus on mathematics. Paradoxically, that makes it challenging for us to understand how people behave since the assumption of maximization eliminates volition (as well as makes challenge consideration of time, uncertainty, and ignorance).

Bromley is perhaps more critical of economics, especially the kind that sees efficiency as a guide to policy. To quote Bromley: "Efficiency is not and cannot possibly be a design criterion. The only approach to meaningful institutional change is to: (1) focus on careful diagnosis of problematic settings and circumstances; (2) entertain new ideas that seem most promising in solving a particular problem; (3) embrace the most reasonable of those possibilities; and (4) then undertake ex post monitoring and assessment as the new policies are allowed to run their course" (p. 123). Anyone who agrees with Peter Leeson's (2020) and Yoram Barzel's (2002) eloquent defense of the idea that maximization is a critical concept to economists ought to consider Bromley's explanation why utility maximization cannot provide a guide for human 
action and why efficiency can never explain why we choose a specific policy. Rather, we need to appreciate that the process of institutional change is one of realizing our collective and shared futures through a process of reasoning about what works, what does not work, and how things can be better. ${ }^{15}$

\section{Conclusion}

Is capitalism a liberal emancipatory project worth saving? Or is it a spent force? Boettke does a masterful job clarifying what capitalism does well, explaining the problems arising from centralized-government intervention in the economy, and reminding us of the evils of socialism. But all is not well in the kingdom. Work life is not great, and while nobody doubts that the Bourgeois Deal contributed to riches, it only made some rich. And anger in places such as the rural United States is not simply a consequence of unrestrained government. Capitalism is to blame, according to Bromley, but it is not Adam Smith's capitalism. Managerial capitalism puts workers in a bind, and collective action does not favor the fox.

Despite these differences, there are similarities between Boettke's Austrian institutionalism and Bromley's old institutionalism. Each author sees institutions as the central concern for economics. Boettke is also a self-professed disciple of mainline economics, which includes public choice (clearly concerned with rules) and the Ostroms' polycentric view (also concerned with rules). Still, one discerns a richness in Bromley's analysis of institutions that one does not see as often in much of the mainline tradition, except perhaps for McCloskey's work and, arguably, Boettke's work on socialism. The greatest strength of Boettke's essays may be in the institutional criticism of socialism, and Bromley's most significant contribution is to discern the institutional problem with managerial capitalism. ${ }^{16}$ In my view, these are complementary insights that counsel humility when assessing capitalism and socialism.

The institutional approach of these books has profound policy significance. Much of the current conversation in the post-COVID economy is about infrastructuresome version of a new Marshall Plan, but for the rich countries. This simplistic application of Keynesian reasoning, as these books make so clear, is insufficient because it does not appreciate that the problem is institutional. Boettke and Bromley differ in their diagnosis of the problem; they agree that institutions are the key, and neither proposes a magic bullet. They understand that the process of institutional change is a struggle. Boettke and Bromley also appreciate the significance of ideas in the process of institutional change. Ideas give rise to beliefs, and changes in beliefs ultimately lead to changes in institutions. Their appreciation for ideas, along with history, is too often pushed aside in economics these days.

\footnotetext{
${ }_{15}$ Bromley's Sufficient Reason (2006) more fully develops this argument about beliefs and the process of institutional change.

${ }^{16}$ It would probably make the most sense to accept Smith as the first institutionalist, given his concern with the constitutional rules necessary for a well-functioning market, as Geoffrey Brennan and Buchanan (1985) argued.
} 
There is an important difference when it comes to spontaneous order. Boettke, like the great Austrians before him, appreciates spontaneous order. Hayek famously divided orders into planned and spontaneous orders. Hayek of course followed Menger's distinction between organic and pragmatic orders. Austrian economists tend to see spontaneous orders as the more interesting aspect of social science, while old and new institutionalists tend to see directed orders as more significant, in part because such orders vary so much. Hayek also thought spontaneous order was the most interesting aspect of social science. Bromley shows why there is much we do not understand about the planned orders that are so important to capitalist economies and that there is nothing simple about understanding why and how planner orders work. But Boettke does not succumb to the view that only spontaneous order is interesting or try to define everything as a spontaneous order. Unlike many of the earlier Austrians, who were content to praise the virtues of the market, Boettke has a deep appreciation for Vincent Ostrom's insights into public administration and therefore appreciates the problem of explaining the success of directed orders. Thus, each book can be thought of as a major contribution to institutionalism, however we define it.

Anyone interested in the future of capitalism will be better off after reading these books. The books could be read as a defense of markets and criticism of government by an Austrian-public choice economist versus an impassioned criticism of capitalism by a disciple of the progressive John Commons. But that would be a mistake. Each book illustrates a deep commitment to institutional analysis and offers a wealth of knowledge about how to compare institutions. They both put institutional analysis at the forefront of economics, where it should be. There is no Max $U$ in either of these impressive books. The perspectives are very much complementary. The battle for the future of capitalism is indeed a battle of ideas, and the ideas in these books give us much to reflect on.

Acknowledgments I had the idea to write this essay after a book talk by Dan Bromley at the Center for Governance and Markets at the University of Pittsburgh in March 2021. Mark Pennington served as a discussant for the seminar, and his willingness to engage Dan's book constructively was a breath of fresh air. Mark's constructive dialogue reminded me how much can be gained by carefully considering work with which we disagree. Since I had been reading Pete Boettke's book at the time, it seemed natural to continue that conversation by comparing and contrasting these books. I thank Rosolino Candela for encouraging me to write this piece and for offering extensive and thoughtful suggestions on the essay. Thanks to Nick Cowen, Rabih Helou, and Jen Murtazashvili reding and commenting on the essay and Art Carden for sharing some of his recent work on Walmart that fit nicely with the themes of this essay. Most importantly, thanks to Dan and Pete for their mentorship over the years and for inspiring so many of us.

\section{References}

Aligica, P. D., \& Tarko, V. (2015). Capitalist alternatives: Models, taxonomies, scenarios. Routledge.

Aligica, P. D., Boettke, P. J., \& Tarko, V. (2019). Public Governance and the classical-liberal perspective: Political economy foundations. Oxford University Press.

Anderson, G. M., \& Tollison, R. D. (1982). Adam Smith's analysis of joint-stock companies. Journal of Political Economy, 90(6), 1237-1256.

Barzel, Y. (2002). A theory of the state: Economic rights, legal rights, and the scope of the state. Cambridge University Press. 
Boettke, P. J. (1989a). Evolution and economics: Austrians as institutionalists. Research in the History of Economic Thought and Methodology, 6, 73-89.

Boettke, P. J. (1989b). Austrian institutionalism: A reply. Research in the History of Economic Thought and Methodology, 6, 181-202.

Boettke, P. J. (2001). Calculation and coordination: Essays on socialism and transitional political economy. Routledge.

Boettke, P. J. (2021). The struggle for a better world. Mercatus Center.

Boettke, P. J., Coyne, C. J., \& Leeson, P. T. (2003). Man as machine: The plight of 20th century economics. Annals of the Society for the History of Economic Thought, 43(1), 1-10.

Boettke, P. J., Chamlee-Wright, E., Gordon, P., Ikeda, S., Leeson, P. T., \& Sobel, R. (2007). The political, economic, and social aspects of Katrina. Southern Economic Journal, 74(2), 363-376.

Borjas, G. J. (2016). We wanted workers: Unraveling the immigration narrative. WW Norton \& Company.

Brennan, G., \& Buchanan, J. M. (1985). The reason of rules: Constitutional political economy. Cambridge University Press.

Bromley, D. W. (2006). Sufficient reason: Volitional pragmatism and the meaning of economic institutions. Princeton University Press.

Bromley, D. W. (2019). Possessive individualism: A crisis of capitalism. Oxford University Press.

Carden, A. (2021). July 2, 1962: The Day Retail Changed Forever. American Institute for Economic Research, July 2. https://www.aier.org/article/july-2-1962-the-day-retail-changed-forever/.

Carden, A., \& Courtemanche, C. (2009). Wal-Mart, leisure, and culture. Contemporary Economic Policy, 27(4), 450-461.

Carden, A., Courtemanche, C., \& Meiners, J. (2009). Does Wal-Mart reduce social capital? Public Choice, 138(1-2), 109-136.

Courtemanche, C., \& Carden, A. (2011). Supersizing supercenters? The impact of Walmart supercenters on body mass index and obesity. Journal of Urban Economics, 69(2), 165-181.

Cowen, N. (2021). Neoliberal social justice: Rawls unveiled. Edward Elgar.

Davis, B. R. (2021). Predation in state and nation. Race and Justice, 11(2), 205-225.

Easterly, W. (2020). Progress by consent: Adam Smith as development economist. The Review of Austrian Economics.

Fleury, J.-B., \& Marciano, A. (2018). The sound of silence: A review essay of Nancy MacLean's democracy in chains: The deep history of the radical right's stealth plan for America. Journal of Economic Literature, 56(4), 1492-1537.

Galbraith, J. K. (1967). The new industrial state. Hamish Hamilton.

Harris, C., Cai, M., Murtazashvili, I., \& Murtazashvili, J. B. (2020). The origins and consequences of property rights: Austrian, public choice, and institutional economics perspectives. Cambridge University Press.

Hayek, F. A. (1956 [1994]). The road to serfdom: Fiftieth (anniversary edition). The University of Chicago Press.

Hayek, F. A. (1960). The constitution of liberty. University of Chicago Press.

Hodgson, G. M. (2019). Is socialism feasible?: Towards an alternative future. Edward Elgar Publishing.

Holcombe, R. G. (2018). Political capitalism: How political influence is made and maintained. Cambridge University Press.

Leeson, P. T. (2014). Anarchy unbound: Why self-governance works better than you think. Cambridge University Press.

Leeson, P. T. (2020). Logic is a harsh mistress: Welfare economics for economists. Journal of Institutional Economics, 16(2), 145-150.

Leeson, P. T., \& Harris, C. (Forthcoming). Hayek, neoliberalism, and the Washington consensus. In Candela, R.A. (Ed.), A companion to F.A. Hayek. Universidad Francisco Marroquín.

Magness, P. W., Carden, A., \& Murtazashvili, I. (Forthcoming). "The danger of deplorable reactions:" W.H. Hutt on liberalism, populism, and the constitutional political economy of racism. The Independent Review: A Journal of Political Economy.

McCloskey, D. N. (2019). Why liberalism works: How true liberal values produce a freer, more equal, prosperous world for all. Yale University Press.

McCloskey, D. N. (2010). Bourgeois dignity: Why economics can't explain the modern world. University of Chicago Press.

McCloskey, D. N., \& Carden, A. (2020). Leave me alone and I'll make you rich: How the bourgeois deal enriched the world. University of Chicago Press. 
Meadowcroft, J. (2019). Why are there no Austrian social democrats? Advances in Austrian Economics, $24,89-100$.

Meadowcroft, J., \& Pennington, M. (2008). Bonding and bridging: Social capital and the communitarian critique of liberal markets. The Review of Austrian Economics, 21(2-3), 119-133.

Murtazashvili, J. B., Murtazashvili, I., \& Mylovanov, T. (2021). American institutional exceptionalism and the Trump presidency. The Independent Review: A Journal of Political Economy, 26(1), 97-114.

Nowrasteh, A., \& Powell, B. (2020). Wretched refuse? The political economy of immigration and institutions. Cambridge University Press.

Palagashvili, L., Piano, E., \& Skarbek, D. (2017). The decline and rise of institutions: A modern survey of the Austrian contribution to the economic analysis of institutions. Cambridge University Press.

Piketty, T. (2014). Capital in the twenty-first century. Harvard University Press.

Pistor, K. (2019). The code of capital: How the law creates wealth and inequality. Princeton University Press.

Rosenberg, N. (1960). Some institutional aspects of the wealth of nations. Journal of Political Economy, $68(6), 557-570$.

Simon, J. L. (1981). The ultimate resource. Princeton University Press.

Somin, I. (2020). Free to move: Foot voting, migration, and political freedom. Oxford University Press.

Storr, V. H., \& Choi, G. (2019). Do markets corrupt our morals? Palgrave Macmillan.

Williamson, C. R., \& Mathers, R. L. (2011). Economic freedom, culture, and growth. Public Choice, $148(3-4), 313-335$.

Publisher's Note Springer Nature remains neutral with regard to jurisdictional claims in published maps and institutional affiliations. 